\title{
Accumulation of Short $n$-Chain Ethyl Esters by Esterases of Lactic Acid Bacteria Under Conditions Simulating Ripening Parmesan Cheese
}

\author{
K. M. Fenster, S. A. Rankin, and J. L. Steele \\ *Department of Food Science, University of Wisconsin-Madison, \\ Madison 53706
}

\begin{abstract}
EstA from Lactobacillus helveticus CNRZ32 (LbhEstA), EstB, and EstC from Lactobacillus casei LILA, and EstA from Lactococcus lactis MG1363 (Lcl-EstA) were evaluated for their ability to accumulate esters in a model system simulating Parmesan cheese ripening conditions $\left(10^{\circ} \mathrm{C}, 2\right.$ to $3 \% \mathrm{NaCl}, \mathrm{pH} 5.4$ to $5.5, \mathrm{a}_{\mathrm{w}}=0.850$ to 0.925$)$ using Capalase $\mathrm{K}$ from kid goat as a positive control. All of the LAB esterases and Capalase K mediated the accumulation of esters in the model system in an enzyme specific manner, which was influenced by $\mathrm{a}_{\mathrm{w}}$ and selectivity for fatty acid chain-length. In general, enzyme mediated accumulation of ethyl esters was higher at $\mathrm{a}_{\mathrm{w}}$ values of 0.850 and 0.900 than at $\mathrm{a}_{\mathrm{w}}$ of 0.925 , demonstrating that $\mathrm{a}_{\mathrm{w}}$ is a critical parameter influencing ester accumulation. The substrate selectivity of esterases, $a_{w}$, and enzyme type may be important factors in the development of fruity flavors, as evidenced by results in this model system simulating Parmesan cheese ripening conditions.
\end{abstract}

(Key words: esterase, ester accumulation, Parmesan cheese)

Abbreviation key: $\mathbf{a}_{\mathbf{w}}=$ water activity, $\mathbf{F A}=$ fatty acid, $\mathbf{L A B}=$ lactic acid bacteria, PGL = pregastric lingual lipase, $\boldsymbol{p} \mathbf{N P}=p$-nitrophenyl.

\section{INTRODUCTION}

Ripening of hard Italian cheeses, such as Romano, Parmesan, and Grana Padano is a lengthy and complex process (Kosikowski, 1977; Battistotti and Corradini, 1993). Esterases and lipases are important for the characteristic flavor development of Italian cheeses (Ha and Lindsay, 1992; Gobbetti et al., 1997b). In general, esterases and lipases have the capacity to influence Italian cheese flavor by both hydrolyzing and synthesizing es-

Received December 13, 2002.

Accepted March 4, 2003.

Corresponding author: J. L. Steele; e-mail: jlsteele@facstaff. wisc.edu. ters (Ha and Lindsay, 1992; Moio and Addeo, 1998). The equilibrium existing between these processes is dependent on the water activity $\left(\mathbf{a}_{\mathbf{w}}\right)$, the enzymes present, $\mathrm{pH}$, temperature, and availability of both fatty acids (FA) and alcohols characteristic of each cheese variety (Ha and Lindsay, 1992; Moio and Addeo, 1998).

The formation of ethyl esters such as ethyl butanoate and ethyl hexanoate are believed to play an important role in the development of characteristic fruity flavors in Italian cheeses such as Parmesan and Grana Padano (Dumont et al., 1974; Meinhart and Schreier, 1986; Barbieri et al., 1994; Moio and Addeo, 1998; Qian and Reineccius, 2002). The FA and ester profiles of each Italian cheese are variety dependent and modulated by the selectivities of the lipolytic and esterolytic enzymes involved in cheese ripening (Woo and Lindsay, 1984; Ha and Lindsay, 1992).

Lipolytic enzymes involved in flavor development of Italian cheese originate from milk, the starter culture employed, nonstarter lactic acid bacteria (LAB), and pregastric tissues of ruminants (Fox and Cogan, 2000). Endogenous milk lipase is abundant in milk and could contribute to lipolysis in cheese manufactured from raw milk (Fox et al., 2000). However, when milk is pasteurized $\left(78^{\circ} \mathrm{C} / 10 \mathrm{~s}\right)$, milk lipase is inactivated and unlikely to contribute to flavor development (Fox et al., 2000). Pregastric lingual lipases (PGL) from calf, kid goat, or lamb, are used in the manufacture of Romano and Provolone cheeses (Ha and Lindsay, 1993; Fox et al., 2000). The use of PGL in cheese results in extensive lipolysis of milk fat and the development of sharp, peppery, and "picante" flavor notes (Gobbetti et al., 1997b; Fox et al., 2000). In other Italian cheeses, such as Parmesan and Grana Padano, PGL is not used (Johnson, 2001). These latter cheeses are typified by the tendency to develop more fruity flavors and less intense lipolytic flavor notes (Barbieri et al., 1994; Johnson, 2001; Qian and Reineccius, 2002).

Little is known about the contribution of lipases and esterases from LAB to the formation of flavor in Italiantype cheeses, such as Parmesan and Grana Padano (Moio and Addeo, 1998; Fox and Cogan, 2000). Presumably, 
esterases, and lipases from starter LAB, such as Lactobacillus helveticus, Lactobacillus delbrueckii, Lactobacillus fermentum, and Streptococcus theromophilus, and nonstarter LAB, such as Lactobacillus casei, are responsible for liberating short $n$-chain FA from milk fat at elevated $\mathrm{a}_{\mathrm{w}}$ and synthesis of short $n$-chain ethyl esters as $\mathrm{a}_{\mathrm{w}}$ decreases with ripening (Ha and Lindsay, 1992). Given the high cell densities reached by starter and nonstarter LAB ( $10^{8}$ to $10^{9} \mathrm{cfu} / \mathrm{g}$ cheese) as well as the lengthy ripening time associated with these cheeses, lipases, and esterases from LAB are likely to play an important role in flavor development of these cheeses (Gobbetti et al., 1996a, 1997b).

The esterolytic and lipolytic activities of several thermophilic and mesophilic lactobacilli have been described (Gobbetti et al., 1996a). Esterases and lipases of LAB have recently been characterized from $L b$. casei (Fenster et al., 2003a; Fenster et al., 2003b; Castillo et al., 1999), Lb. plantarum (Gobbetti et al., 1996a, 1997a), Lb. fermentum (Gobbetti et al., 1997b), Lb. helveticus (Fenster et al., 2000, 2003b), Lactococcus lactis (Tsakalidou and Kalantzopoulos, 1992; Holland and Coolbear, 1996; Chich et al., 1997; Fernández et al., 2000; Fenster et al., 2003a), and S. thermophilus (Liu et al., 2001). In most cases, the selectivities of these enzymes for hydrolyzing ester compounds under cheese-like and noncheese-like conditions were evaluated. The activities and selectivities of these enzymes for esters with short $n$-chain FA suggest that some of these esterases and lipases could have a significant effect on cheese flavor development. However, the influence of $a_{w}$ on the ability of these enzymes to synthesize esters, especially under conditions found in low moisture cheeses, such as Parmesan and Grana Padano, has not been evaluated.

Because the activities and specificities of esterases and lipases vary widely between species and strains of LAB (Gobbetti et al., 1996a), selection of appropriate starter and adjunct starter LAB for cheese manufacture may be especially important for bacterial ripened cheeses, such as Parmesan and Grana Padano, where accumulation of ethyl esters, such as ethyl butanoate and ethyl hexanoate, are believed to be essential for characteristic flavor development (Dumont et al., 1974; Meinhart and Schreier, 1986; Barbieri et al., 1994; Moio and Addeo, 1998; Qian and Reineccius, 2002).

This manuscript describes the selectivity for and accumulation of ethyl esters catalyzed by EstA from $L b$. helveticus CNRZ32 (Lbh-EstA), EstB, and EstC from $L b$. casei LILA, and EstA from Lc. lactis MG1363 (Lcl-EstA) in a model system simulating Parmesan cheese ripening conditions $\left(10^{\circ} \mathrm{C}, 2\right.$ to $3 \% \mathrm{NaCl}, \mathrm{pH} 5.4$ to 5.5). Modulation of esterase activity by $\mathrm{a}_{\mathrm{w}}$ values of 0.850 to 0.925 was determined. The potential role of these esterases in cheese flavor development is discussed based on their ability to mediate ester accumulation at $\mathrm{a}_{\mathrm{w}}$ values typically encountered in ripening Parmesan cheese.

\section{MATERIALS AND METHODS}

\section{Purification of Esterases}

Lbh-EstA, EstB, EstC, and Lcl-EstA were previously purified to electrophoretic homogeneity by affinity chromatography (Fenster et al., 2000, 2003a, 2003b) using the QIAexpressionist Protein Purification System (Qiagen, Inc., Chatsworth, CA) according to the manufacturer's instructions. Briefly, Lbh-EstA, EstB, EstC, and LclEstA were overexpressed with $\mathrm{N}$-terminal or C-terminal (His) $)_{6}$ tags in Escherichia coli. One-step purification of these enzymes was based on affinity of the (His) ${ }_{6}$ tag for Ni-nitrilotriacetic acid, desorbing non-(His) ${ }_{6}$ tagged proteins with $50 \mathrm{~m} M$ Na-phosphate ( $\mathrm{pH} 8.0), 300 \mathrm{~m} M$ $\mathrm{NaCl}$, and $10 \mathrm{~m} M$ histidine, and then eluting the target protein with a gradient of histidine from 10 to $500 \mathrm{mM}$. Protein profiles in collected fractions were visualized on vertical 12\% SDS-PAGE gels (Sambrook et al., 1989). Fractions containing Lbh-EstA-(His) $)_{6}$ EstB-(His) $)_{6}$, EstC-(His) $)_{6}$, or Lcl-EstA-(His) $)_{6}$ were pooled and dialyzed against $50 \mathrm{~m} M$ Na-phosphate (pH 8.0) and $300 \mathrm{~m} M \mathrm{NaCl}$ at $4^{\circ} \mathrm{C}$.

\section{Determination of Esterase and Lipase Activities}

Enzyme activities of purified Lbh-EstA, EstB, EstC, and Lcl-EstA were determined with $p$-nitrophenyl ( $\boldsymbol{p N P}$ ) butanoate (Sigma Chemical Co., St. Louis, MO) as previously described (Fenster et al., 2000, 2003a, 2003b). The enzyme activity of Capalase K (Degussa Bioactives, Waukesha, WI), a kid goat PGL, was determined with $p$ NP-butanoate in a similar fashion. Briefly, $1 \mathrm{~g}$ of Capalase $\mathrm{K}$ was mixed in $20 \mathrm{ml}$ of ice-cold $50 \mathrm{mM}$ Na-phosphate $(\mathrm{pH} \mathrm{5.0)}$ and $150 \mathrm{mM} \mathrm{NaCl}$. Insoluble material was removed by centrifugation $\left(1940 \times g, 10 \mathrm{~min}, 4^{\circ} \mathrm{C}\right)$. The protein content was determined with the Sigma Total Protein Kit using bovine serum albumin (Sigma) as the standard. The standard assay mixture consisted of $50 \mathrm{~m} M$ Na-phosphate (pH 5.0) and $150 \mathrm{~m} M \mathrm{NaCl}$, which was $\mathrm{pH}$-adjusted at the temperature $\left(50^{\circ} \mathrm{C}\right)$ used for the enzyme assays. Reaction mixtures $(1 \mathrm{ml}$ total reaction volume) were preequilibrated for $5 \mathrm{~min}$ at $50^{\circ} \mathrm{C}$ prior to initiation of reactions. Reactions were initiated by adding varying concentrations $(0.0039$ to $4.0 \mathrm{mM})$ of $p$ NP-butanoate and $28 \mu \mathrm{g}$ protein $/ \mathrm{ml}$. Control reactions containing no enzyme were utilized to measure the spontaneous hydrolysis of $p \mathrm{NP}$-butanoate and were deducted from the experimental enzyme assays containing enzyme. Enzyme assays were run continuously for $5 \mathrm{~min}$ and initial rates of $p$-nitrophenol released by Capalase $\mathrm{K}$ were quantified by measuring absorbance at $340 \mathrm{~nm}$ (Martin et al., 
Table 1. Chemical composition of the model cheese system.

\begin{tabular}{|c|c|c|c|}
\hline \multirow{2}{*}{$\begin{array}{l}\text { Chemical } \\
\text { components }\end{array}$} & \multicolumn{3}{|c|}{ Chemical composition (g/100 g) } \\
\hline & $\mathrm{a}_{\mathrm{w}}=0.925$ & $\mathrm{a}_{\mathrm{w}}=0.900$ & $\mathrm{a}_{\mathrm{w}}=0.850$ \\
\hline Total moisture ${ }^{1}$ & 40.4 & 33.1 & 25.8 \\
\hline Casein & 46.3 & 52.0 & 57.8 \\
\hline Casein hydrolysate & 1.32 & 1.49 & 1.65 \\
\hline $\mathrm{NaCl}$ & 2.60 & 2.93 & 3.25 \\
\hline Calcium phosphate & 7.33 & 8.24 & 9.15 \\
\hline Natamax & 1.01 & 1.14 & 1.26 \\
\hline Fatty acids and alcohols & 1.00 & 1.00 & 1.00 \\
\hline Kanamycin & 0.011 & 0.012 & 0.013 \\
\hline Ampicillin & 0.011 & 0.012 & 0.013 \\
\hline Penicillin & 0.011 & 0.012 & 0.013 \\
\hline Erythromycin & 0.011 & 0.012 & 0.013 \\
\hline
\end{tabular}

${ }^{1}$ Total moisture includes weight of sterile water and $5 M \mathrm{NaOH}$ used to adjust $\mathrm{pH}$ to 5.4 to 5.5 .

1959). The extinction coefficient $\left(\varepsilon_{\mathrm{m} M}\right)$ of $p$-nitrophenol under these conditions was determined to be $7.25 / \mathrm{cm}$ at $340 \mathrm{~nm}$. Measured reaction rates were verified to be linear under these conditions. Enzyme assays were performed twice in duplicate and the coefficient of variation was $\leq 5 \%$. Kinetic constants $\left(\mathrm{K}_{\mathrm{M}}\right.$ and $\left.\mathrm{V}_{\max }\right)$ were calculated from the Hyperbola (Hyperbol.fit) program of Sigma Plot 3.0 (Jandel Scientific Software, San Rafael, CA). The specific activity of Capalase $\mathrm{K}$ was expressed as $\mu \mathrm{mol} p$-nitrophenol/min per milligram of protein.

\section{Preparation of Model Cheese Systems}

The formulations for the model systems employed in this study are presented in Table 1 . The standard procedure for making the model systems with $\mathrm{a}_{\mathrm{w}}$ values of $0.925,0.900$, and $0.850( \pm 0.003$; measurements done in triplicate) was as follows. $\mathrm{NaCl}$ (Sigma) was dissolved in sterile water. Calcium phosphate (Sigma) was added and stirred for $10 \mathrm{~min}$. The $\mathrm{pH}$ was adjusted to 5.4 to 5.5 by adding $5 \mathrm{M} \mathrm{NaOH}$. The casein hydrolysate (Sigma), Natamax (Danisco Cultor USA, Inc., New Century, KS), and antibiotics (kanamycin, ampicillin, penicillin, and erythromycin; Sigma) were added and stirred for $5 \mathrm{~min}$. The Natamax and antibiotics were incorporated into the model system to suppress growth of yeasts, molds, and bacteria. HPLC-grade 1-heptanol was added as an internal standard at a concentration of $1000 \mathrm{mg} / \mathrm{kg}$; alcohols (ethanol, 1-propanol, 1-butanol, 1-pentanol, and 1-hexanol) and fatty acids (acetic, propionic, butanoic, pentanoic, and hexanoic acids) (Sigma) were added at a concentration of $1000 \mathrm{mg} / \mathrm{kg}$ each in the model system and stirred for $5 \mathrm{~min}$. The $\mathrm{pH}$ of the model system was readjusted to $\mathrm{pH} 5.4$ to 5.5 with $5 \mathrm{M} \mathrm{NaOH}$. Purified casein (Sigma) was added and stirred for $10 \mathrm{~min}$. The $\mathrm{a}_{\mathrm{w}}$ of each model system was determined with a Decagon CX2 water activity meter (Decagon Devices, Inc., Pullman, WA) according to the manufacturer's instructions.

\section{Synthesis of Esters in Model Cheese Systems}

The purified LAB esterases were individually added on a weight basis (35 $\mu \mathrm{g}$ each) to $10 \mathrm{~g}$ of model system. Capalase K, which was previously observed to synthesize ethyl esters under cheese-like conditions (Ha and Lindsay, 1992), was used as a positive control for ester synthesis in this study. Because Capalase $\mathrm{K}$ was not a pure enzyme preparation, the addition of $6.9 \mathrm{mg}$ of this enzyme to the model system was based on that quantity of enzyme, which had activity on $p$ NP-butanoate that was within the range of activities for the LAB esterases. Spontaneous synthesis of esters was determined using samples with no enzyme and by adding heat-inactivated Capalase K (boiled for 10 min). Each enzyme was examined in duplicate at each $\mathrm{a}_{\mathrm{w}}$ tested.

After addition of enzyme, 10 -g samples were transferred to 50-ml glass crimp top vials (Supelco, Bellefonte, PA) with Teflon (DuPont, Wilmington, DE) septa and aluminum crimp top seals and then stored at $10^{\circ} \mathrm{C}$ for $60 \mathrm{~d}$.

\section{Microbial and Fungal Enumeration}

Enumeration of aerobic bacteria, coliforms, and yeast and molds was conducted to determine general microbial and fungal quality of the model systems (Petrifilm, 3M Microbiology Products, St. Paul, MN) according to the manufacturer's instructions.

\section{Ester Quantification}

Esters were quantified using a dynamic headspace system similar to Colchin et al. (2001). Briefly, $5.0 \mathrm{~g}$ of sample was transferred into a $100-\mathrm{ml}$ round bottom single neck flask fitted with a glass adapter, which contained a hose connector and an open top compression cap (Kimble/Kontes, Vineland, NJ). Samples were purged with purified nitrogen gas $(500 \mathrm{ml} / \mathrm{min})$ for 30 
min at $25^{\circ} \mathrm{C}$. Displaced headspace volatiles were trapped onto Orbo-100 (Supelco, Inc., Bellefonte, PA) solvent desorption tubes. Volatiles were desorbed with HPLCgrade diethyl ether (Sigma) into graduated screw top vials $(2 \mathrm{ml})$ with solid caps and Teflon (DuPont) liners; a total of $1.0 \mathrm{ml}$ of solvent eluate was collected. No additional concentration was performed prior to injection.

\section{Gas Chromatography-Mass Spectroscopy GC/MS}

Samples were analyzed with a GC (Hewlett-Packard 6890; Hewlett-Packard Company, Palo Alto, CA) equipped with a mass selective detector (5973 HewlettPackard with Hewlett-Packard B.02.05 ChemStation software). An HP-5, 30-m $\times 0.25$-mm inner diameter, 0.5$\mu \mathrm{m}$ film thickness column (Hewlett-Packard) was used for the resolution of volatile compounds.

Sample injections of $1 \mu \mathrm{l}$ were made in the split mode at a $40: 1$ ratio. The initial column temperature was $30^{\circ} \mathrm{C}$, which was held for $4 \mathrm{~min}$, then increased at $4^{\circ} \mathrm{C} / \mathrm{min}$ to $95^{\circ} \mathrm{C}$. The column temperature was increased at $30^{\circ} \mathrm{C} /$ min to $220^{\circ} \mathrm{C}$ and maintained for $10 \mathrm{~min}$. Column flow rate was $1.0 \mathrm{ml} / \mathrm{min}$ using helium as the carrier gas. The mass-spectrometer operating conditions used were ion source temperature of $230^{\circ} \mathrm{C}$, ionization voltage of $70 \mathrm{eV}$, and scan range of 20 to $350 \mathrm{~m} / z$ at $2.76 \mathrm{scans} / \mathrm{s}$.

\section{Identification and Quantification}

Compounds were identified by comparison to a mass spectral reference collection (NIST 1998 Mass Spectral Library, version 1.7) and by retention times of known standards. Quantification was based on standardized peak areas (total mass ion abundance) of authentic standards. The standard curves for ethyl butanoate, ethyl pentanoate, ethyl hexanoate, and 1-heptanol were established from 1 to $100 \mathrm{mg} / \mathrm{kg}$ using the model system as a base. The purge-trap technique, GC-MS, and identification methods used to establish the standard curves were identical to those used for the experimental samples. To solely evaluate the effects of enzyme-mediated ester generating reactions, the values presented were further corrected by subtracting the average ester concentrations formed spontaneously in the negative controls. The negative controls contained either no added enzyme or had heat-inactivated Capalase K. The accumulation of esters catalyzed by each of the enzymes was at least 2 times greater than the average concentrations due to spontaneous formation observed in the negative controls.

\section{Statistical Analysis}

Statistical analyses were performed using a completely random design (JMP version 6.12; SAS Institute,
Table 2. Hydrolysis of $p$-nitrophenyl butanoate by kid goat Capalase K, EstA from Lactobacillus helveticus CNRZ32 (Lbh-EstA), EstB, and EstC from Lb. casei LILA, and EstA from Lactococcus lactis MG1363 (Lcl-EstA).

\begin{tabular}{llcc}
\hline Enzyme & $\mathrm{K}_{\mathrm{M}}{ }^{1}$ & $\mathrm{~V}_{\max }{ }^{2}$ & $\mathrm{~V}_{\max } / \mathrm{K}_{\mathrm{M}}$ \\
\hline Capalase K & 0.34 & 0.62 & 1.8 \\
Lbh-EstA & 0.17 & 150 & 880 \\
EstB & 0.33 & 17 & 45 \\
EstC & 0.097 & 63 & 650 \\
Lcl-EstA & 0.28 & 58 & 93 \\
\hline${ }^{1} \mathrm{~m} M$. & & \\
${ }^{2} \mu \mathrm{mol} / \mathrm{mg}$ per minute. & &
\end{tabular}

Inc., Cary, NC). Tukey pairwise mean comparisons were performed where appropriate $(\alpha \leq 0.05)$.

\section{RESULTS AND DISCUSSION}

\section{Esterase and Lipase Activities}

The kinetic constants $\left(\mathrm{K}_{\mathrm{M}}\right.$ and $\left.\mathrm{V}_{\mathrm{max}}\right)$ for the hydrolysis of $p$ NP-butanoate by Capalase K, Lbh-EstA, EstB, EstC, and Lcl-EstA are presented in Table 2. The kinetic values obtained for the LAB esterases were consistent with those from previous characterizations of these enzymes (Fenster et al., 2003a, 2003b) and indicate that the enzymes are active (and suitable) for evaluation in the model system.

\section{Microbial and Fungal Enumeration}

The levels of aerobic bacteria, coliform, and yeast and molds were $<1 \mathrm{cfu} / \mathrm{g}$ of model system, which indicates that esterases and lipases from these sources did not contribute to ester accumulation in the model system.

\section{Statistical Analyses}

The complete statistical model of the main and corresponding two-way interaction effects of enzyme type, $a_{w}$, and enzyme selectivity for FA chain length are presented in Table 3. In short, each of the main and two-way interactions had significant effects $(P<5 \%)$ on the accumulation of esters evaluated in this system; each is described in detail below.

\section{Overall Esterase Selectivity}

To investigate the effects of substrate variation on enzyme selectivity, FA (acetic, propionic, butyric, pentanoic, and hexanoic acids) and alcohols (ethanol, 1-propanol, 1-butanol, 1-pentanol, and 1-hexanol) were added at a concentration of $1000 \mathrm{mg} / \mathrm{kg}$ to the model systems. Based on a limit of detection of approximately $0.1 \mathrm{mg} /$ $\mathrm{kg}$, the only esters identified in this study were ethyl 
butanoate, ethyl pentanoate, and ethyl hexanoate. Pooling the effects of enzyme and $\mathrm{a}_{\mathrm{w}}$ resulted in ethyl ester concentrations of $26.6 \pm 3.6,27.0 \pm 5.1$, and $32.0 \pm 5.1$ $\mathrm{mg} / \mathrm{kg}$ for ethyl butanoate, ethyl pentanoate, and ethyl hexanoate, respectively. These results revealed general trends favoring the accumulation of ethyl esters as well as accumulation of these esters with increasing fatty acid chain length. Preferential accumulation of these esters may result from several factors including the innate selectivity and activity of the esterases for a particular substrate, the differential partitioning of substrate and product within the components of the model system and concomitant accessibility of enzymes to the substrate, and the stability of esters in the model system as designed. However, the trend toward selection of esters with longer chain lengths was not consistent across every enzyme and $\mathrm{a}_{\mathrm{w}}$ treatment.

\section{Influence of Enzyme on Accumulation of Ethyl Esters}

Pooling the effects of $a_{w}$ and the type of ethyl ester formed, the concentration of total enzyme-derived esters were 5.6 $\pm 1.5,7.5 \pm 1.8,32.6 \pm 3.3,37.1 \pm 3.7$, and 60.1 $\pm 5.8 \mathrm{mg} / \mathrm{kg}$ for the Lbh-EstA, EstC, Capalase K, LclEstA, and EstB, respectively. The concentrations of ethyl esters catalyzed by each of the enzymes were significantly different from each other with the exception of Lbh-EstA and EstC, which exhibited the lowest accumulation level among the enzymes examined. EstB catalyzed the highest level of accumulation of ethyl esters, which was 8 to 11 times higher than in samples with Lbh-EstA and EstC. In general, this selectivity pattern was fairly consistent across each $a_{w}$ value and each of the three FA chain lengths; however, some deviations are of particular significance, as detailed in appropriate sections below.

The differences in enzyme-mediated ester accumulation concentrations could be influenced by the inherent relative rates of synthesis and hydrolysis of ethyl esters by the enzymes, access to cosubstrates, and environmental factors, such as $\mathrm{pH}$, salt, temperature, and $\mathrm{a}_{\mathrm{w}}$. In previous characterizations of Lbh-EstA, EstB, EstC, and
Lcl-EstA (Fenster et al., 2000, 2003a, 2003b), the individual effects of $\mathrm{pH}$, salt $(\mathrm{NaCl})$, and temperature on ester hydrolyzing activities of these enzymes were evaluated. As previously reported, reduction in $\mathrm{pH}$ from near neutrality ( $\mathrm{pH} 7.0$ to 8.0 ) to values typical of cheese $(\mathrm{pH}$ $<5.5$ ) had a pronounced effect on reducing the activities of Lbh-EstA and Lcl-EstA, yet little effect on EstB and EstC. This suggests that $\mathrm{pH}$ may be the primary factor likely to affect activities of Lbh-EstA and Lcl-EstA under cheese-like conditions employed in the current study. Additionally, $\mathrm{NaCl}$ inhibited EstC activity to a significantly greater extent than that observed for the other LAB esterases (Fenster et al., 2003a). Therefore, $\mathrm{NaCl}$ concentration is likely the primary factor affecting the residual activity of this enzyme under the cheese-like conditions manifest in the model system. Both $\mathrm{pH}$ and $\mathrm{NaCl}$ concentration are likely to contribute to the lower ethyl ester concentrations observed in the model cheeses containing Lbh-EstA and EstC. Because Lbh-EstA and Lcl-EstA are both similarly influenced by $\mathrm{pH}$, the higher level of ethyl ester accumulation mediated by Lcl-EstA suggests that selectivity for cosubstrates, or relative rates of synthesis and hydrolysis of ethyl esters, may be important factors contributing to the accumulation of ethyl esters catalyzed by these enzymes.

\section{Effect of $a_{w}$ on Accumulation of Ethyl Esters}

Accumulation of ethyl butanoate, ethyl pentanoate, and ethyl hexanoate occurred at each of the $a_{w}$ values evaluated. Pooling the effects of enzyme and type of ester resulted in ethyl ester concentrations of $34.0 \pm 5.4,36.0$ \pm 4.7 , and $15.8 \pm 2.3$ for $\mathrm{a}_{\mathrm{w}}$ values of $0.850,0.900$, and 0.925 , respectively. In general, ethyl ester accumulation was favored at lower $a_{w}$ values. Ester concentrations at $\mathrm{a}_{\mathrm{w}}$ values of 0.850 and 0.900 were indistinguishable from one another and were 2.2 to 2.3 times greater than the concentrations at 0.925 . The effect of $\mathrm{a}_{\mathrm{w}}$ was neither consistent across enzyme treatment nor FA chain length selectivity.

Table 3. ANOVA table for evaluating enzyme application, water activity $\left(\mathrm{a}_{\mathrm{w}}\right)$, and selectivity for fatty acid (FA) chain length on formation of ethyl butanoate, ethyl pentanoate, and ethyl hexanoate.

\begin{tabular}{lcccc}
\hline Parameter & $\begin{array}{l}\text { Degrees of } \\
\text { freedom }\end{array}$ & $\begin{array}{l}\text { Sum of } \\
\text { squares }\end{array}$ & $F$ Ratio & Probability $>F$ \\
\hline Enzyme & 5 & 57,900 & 877 & $<0.0001$ \\
$\mathrm{a}_{\mathrm{w}}$ & 2 & 6750 & 255 & $<0.0001$ \\
FA chain length & 2 & 7800 & 59.1 & $<0.0001$ \\
Enzyme $\times \mathrm{a}_{\mathrm{w}}$ & 10 & 501 & 18.0 & $<0.0001$ \\
Enzyme $\times$ FA chain length & 10 & 4110 & 31.2 & $<0.0001$ \\
$\mathrm{a}_{\mathrm{w}} \times$ FA chain length & 4 & 341 & 6.46 & $<0.0002$ \\
\hline
\end{tabular}




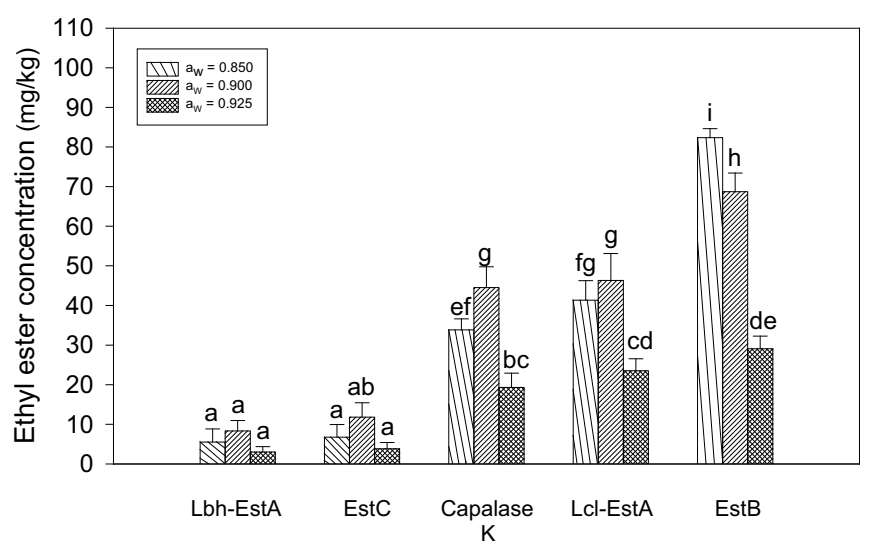

Figure 1. Bar chart depicting the influence of enzyme type and $\mathrm{a}_{\mathrm{w}}$ on cumulative concentrations of ethyl butanoate, ethyl pentanoate, and ethyl hexanoate. Values were corrected by subtracting the levels of esters formed spontaneously in the control treatments. Bars represent mean values; error bars represent one standard error of the mean $(n=2)$. Bars with different letters denote statistically different means at the $\alpha \leq 0.05$ level.

\section{Influence of Enzyme and $a_{w}$ on Accumulation of Ethyl Esters}

The interaction between esterases and $a_{w}$ values on total ester accumulation is presented in Figure 1. The accumulation of ethyl esters catalyzed by Lbh-EstA, EstC, Capalase $\mathrm{K}$, and Lcl-EstA treatments at each $\mathrm{a}_{\mathrm{w}}$ $(0.850,0.900,0.925)$ exhibited a similar trend for the highest ester concentrations at the intermediate $a_{w}$ value of 0.900 , and the lowest ester concentrations at the highest $\mathrm{a}_{\mathrm{w}}$ value of 0.925 . Although apparent as a trend, this pattern only reached statistical significance with the Capalase $\mathrm{K}$ and Lcl-EstA treatments. The inability to observe a reduction in ethyl ester accumulation at an $\mathrm{a}_{\mathrm{w}}$ of 0.925 with Lbh-EstA and EstC is likely due to their relatively low levels of accumulation. The EstB treatment was an exception to this trend in that it had greatest ester accumulation at the lowest $\mathrm{a}_{\mathrm{w}}$ value of 0.850 .

There were pronounced differences between the enzymes in their ability to catalyze the accumulation of ethyl esters at the $\mathrm{a}_{\mathrm{w}}$ values examined. The largest differences observed were between EstB $\left(a_{w}=0.850\right)$ and LbhEstA $\left(a_{w}=0.925\right)$; under these conditions, EstB catalyzed the accumulation of ethyl esters at a level 27 times higher than that observed with Lbh-EstA.

These results largely support the hypothesis of $\mathrm{Ha}$ and Lindsay (1992) that decreases in $\mathrm{a}_{\mathrm{w}}$ in ripening Italiantype cheeses favors the synthesis of ethyl esters. The observed influence of $a_{w}$ on ethyl ester accumulation is likely to be important for flavor development of hard Italian cheeses, such as Parmesan and Grana Padano, because the $\mathrm{a}_{\mathrm{w}}$ of these cheeses typically decrease during ripening (Ha and Lindsay, 1992; Coppola et al., 2000).

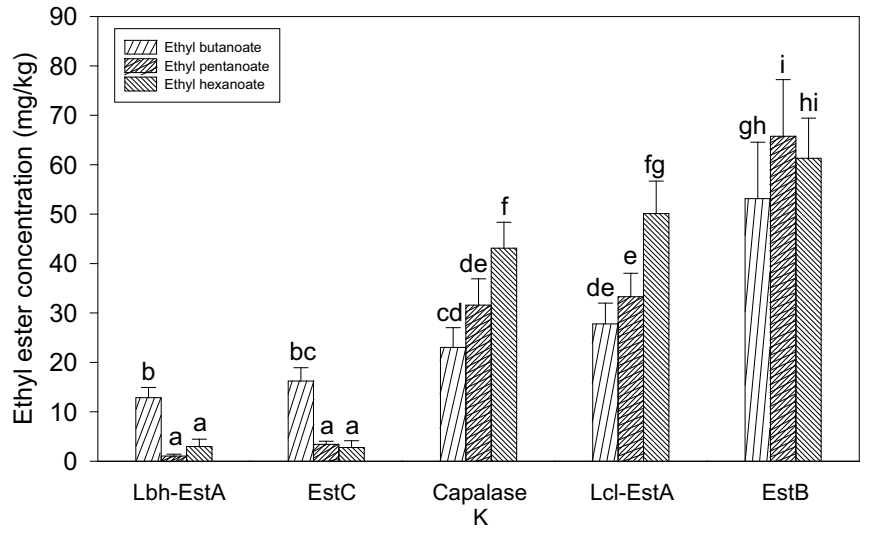

Figure 2. Bar chart depicting the enzyme-specific selectivity for butanoate, pentanoate, and hexanoate. Values were corrected by subtracting the levels of esters formed spontaneously in the control treatments. Bars represent mean values; error bars represent one standard error of the mean $(n=2)$. Bars with different letters denote statistically different means at the $\alpha \leq 0.05$ level.

After ripening for 1 to $2 \mathrm{yr}$, the interior and exterior of Parmesan develop $\mathrm{a}_{\mathrm{w}}$ values of 0.91 to 0.92 and 0.85 to 0.88, respectively (Rüegg and Blanc, 1981; Battistotti and Corradini, 1993). The decreasing $a_{w}$ of these cheeses during ripening favors ester synthesis by esterases and lipases (Ha and Lindsay, 1992; Cristiani and Monnet, 2001).

\section{Enzyme-Mediated Selectivity for Ethyl Butanoate, Ethyl Pentanoate, and Ethyl Hexanoate}

The effects of enzyme selectivity for ethyl butanoate, ethyl pentanoate, and ethyl hexanoate are presented in Figure 2. Both Lbh-EstA and EstC produced similar concentrations of ethyl esters, which were the lowest among the enzymes examined. Additionally, the Lbh-EstA and EstC enzymes exhibited the selective accumulation of 4 to 5 times more ethyl butanoate than either ethyl pentanoate or ethyl hexanoate. Conversely, the Capalase K and Lcl-EstA treatments demonstrated a nearly identical trend for increased ester accumulation levels as a function of increased FA chain length. The selectivity of EstB for butanoate, pentanoate, and hexanoate was substantially different from the other enzymes examined, yielding the highest concentrations of each of the ethyl esters. This was most pronounced in the accumulation of ethyl pentanoate, for which EstB resulted in the accumulation of a 65-fold higher level than Lbh-EstA. There were only minor differences in the selectivity of EstB among ethyl butanoate, ethyl pentanoate, and ethyl hexanoate.

Previous characterizations of Lbh-EstA and EstC revealed that these enzymes selectively hydrolyzed $p \mathrm{NP}$ 
esters with FA chain lengths of C2-C4 and C3-C4, respectively (Fenster et al., 2000, 2003a, 2003b). However, the selectivity of these enzymes decreased with FA chain lengths longer than $\mathrm{C} 4$. These results suggest that the hydrophobic binding pockets of Lbh-EstA and EstC are better able to accommodate FA chain-lengths of $\mathrm{C} 4$ than either C5 or C6. Lcl-EstA and Capalase K catalyzed the accumulation of ethyl butanoate, ethyl pentanoate, and ethyl hexanoate at levels that were indistinguishable between the two enzymes. Both enzymes resulted in the accumulation of more ethyl hexanoate than either ethyl butanoate or ethyl pentanoate. Previous characterizations of Lcl-EstA revealed that this enzyme selectively hydrolyzed $p \mathrm{NP}$ esters with FA chain lengths of $\mathrm{C} 4$ C6 with the selectivity increasing with FA chain length (Fenster et al., 2003a). Similar selectivities for hydrolysis of short-chain FA esters were also observed with previous characterizations of Capalase K (Lai et al., 1997). Taken together, these results suggest that the hydrophobic binding pockets of Lcl-EstA and Capalase $\mathrm{K}$ are better able to accommodate longer chain FA. EstB resulted in the accumulation of a higher level of ethyl pentanoate than ethyl butanoate. A previous characterization of EstB revealed that this enzyme selectively hydrolyzed $p \mathrm{NP}$ esters with FA chain-lengths of $\mathrm{C} 4-\mathrm{C} 6$ with its catalytic efficiency $\left(\mathrm{V}_{\max } / \mathrm{K}_{\mathrm{M}}\right)$ for $p \mathrm{NP}$-hexanoate being 10 -fold higher than that for $p$ NP-butanoate (Fenster et al., 2003b). These results indicate that while general inferences about specificity of ester synthesis may be possible from hydrolysis data, it is not possible to directly relate the hydrolysis specificity to the synthesis specificity of an enzyme. Perhaps the most significant conclusion that can be drawn from the enzyme specificity data as it relates to ethyl ester accumulation in hard Italian cheese is that it should be possible to control the ratio of ethyl butanoate to ethyl hexanoate by enzyme selection. For example, if a higher level of ethyl butanoate is desired relative to ethyl hexanoate, either Lbh-EstA or EstC would be desirable.

\section{Influence of $a_{w}$ and Enzyme Selectivity for FA Chain Length}

The combined effects of $a_{w}$ and enzyme selectivity for FA chain length on ester accumulation is presented in Figure 3. At an $\mathrm{a}_{\mathrm{w}}$ of 0.850 , no significant differences were observed in the accumulation of ethyl butanoate, ethyl pentanoate, and ethyl hexanoate. At an $\mathrm{a}_{\mathrm{w}}$ of 0.900 , although no significant differences were observed in the accumulation of ethyl butanoate and ethyl pentanoate, there was a trend towards increased accumulation of esters as a function of increasing FA chain length. This trend was also manifest at an $a_{w}$ of 0.925 , where ethyl

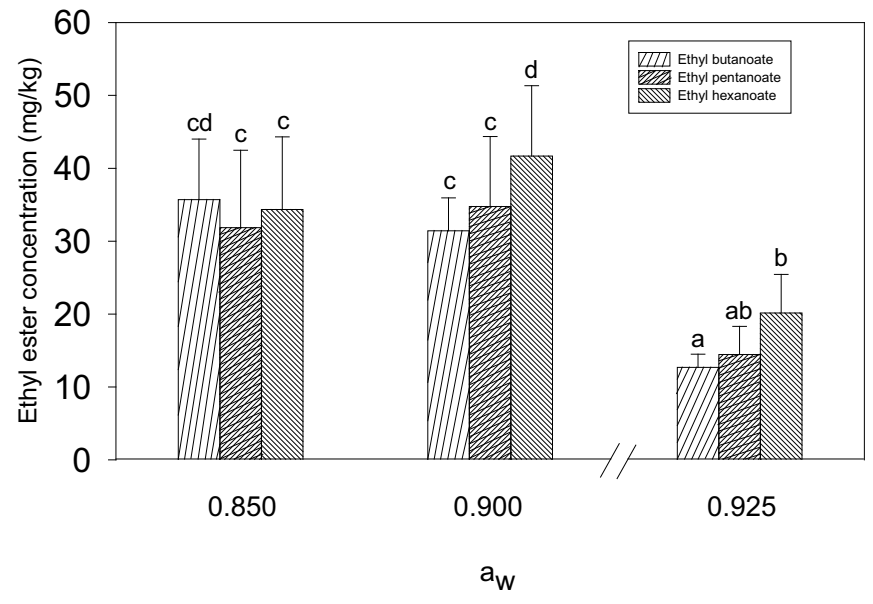

Figure 3. Bar chart depicting the effect of $a_{w}$ on accumulation of ethyl butanoate, ethyl pentanoate, and ethyl hexanoate. Values were corrected by subtracting the levels of esters formed spontaneously in the control treatments. Bars represent mean values; error bars represent one standard error of the mean $(n=2)$. Bars with different letters denote statistically different means at the $\alpha \leq 0.05$ level.

hexanoate accumulated to a significantly higher level than ethyl butanoate.

In Parmesan and Grana Padano cheeses, ethyl butanoate and ethyl hexanoate are believed to play an important role in the formation of the characteristic fruity flavors associated with these cheese varieties (Dumont et al., 1974; Meinhart and Schreier, 1986; Barbieri et al., 1994; Moio and Addeo, 1998; Qian and Reineccius, 2002). Also, the accumulation of ethyl butanoate and ethyl hexanoate is believed to be dependent on the presence of cosubstrates (ethanol, butanoic acid, and hexanoic acid), an enzyme capable of synthesizing these ethyl esters, and the appropriate environmental conditions (Ha and Lindsay, 1992). Our findings in this study support these previously reported beliefs.

\section{CONCLUSIONS}

In this study, we have demonstrated that esterases from LAB are capable of synthesizing ethyl esters and that the ultimate pool of esters is influenced by the types of enzyme, $a_{w}$, and types of FA available as cosubstrates. Purified esterases from $L b$. helveticus CNRZ32 (LbhEstA), Lb. casei LILA (EstB and EstC), and Lactococcus lactis MG1363 (Lcl-EstA) preferentially accumulated ethyl butanoate, ethyl pentanoate, and ethyl hexanoate in a model system simulating Parmesan cheese ripening conditions $\left(10^{\circ} \mathrm{C}, 2\right.$ to $3 \% \mathrm{NaCl}, \mathrm{pH} 5.4$ to $5.5, \mathrm{a}_{\mathrm{w}}=0.850$ to 0.925$)$. The accumulation of ethyl butanoate, ethyl pentanoate, and ethyl hexanoate in the model system was in an enzyme-specific manner, which was influenced by $\mathrm{a}_{\mathrm{w}}$ and selectivity for FA chain length. Accumulation 
of ethyl esters by these enzymes in the model system was higher at $\mathrm{a}_{\mathrm{w}}$ values of 0.850 and 0.900 , than at $\mathrm{a}_{\mathrm{w}}$ of 0.925 . In this study, it was also demonstrated that $a_{w}$ is a critical parameter influencing ester accumulation by esterases from LAB, and that the substrate selectivity of these esterases could play an important role in cheese flavor development by modulating ester profiles in cheese. Based on our findings and given the high-cell densities of starter and nonstarter LAB present in Parmesan and Grana Padano cheeses, it is likely that esterases from LAB play a central role in the formation of ethyl butanoate and ethyl hexanoate in these cheeses.

\section{ACKNOWLEDGMENT}

This project was funded by Dairy Management, Inc. (Rosemont, IL) through the Wisconsin Center for Dairy Research and the College of Agricultural and Life Sciences at the University of Wisconsin-Madison.

\section{REFERENCES}

Barbieri, G., L. Bolzoni, M. Careri, A. Mangia, G. Parolari, S. Spagnoli, and R. Virgili. 1994. Study of the volatile fraction of Parmesan cheese. J. Agric. Food Chem. 42:1170-1176.

Battistotti, B., and C. Corradini. 1993. Italian cheese. Pages 221-244 in Cheese: Chemistry, Physics, and Microbiology. Vol. 2. P. F. Fox, ed. Chapman \& Hall, London, UK

Castillo, I., T. Requena, P. Fernandez de Palencia, J. Fontecha, and M. Gobbetti. 1999. Isolation and characterization of an intracellular esterase from Lactobacillus casei subsp. casei IFPL731. J. Appl. Microbiol. 86:653-659.

Chich, J.-F., K. Marchesseau, and J.-C. Gripon. 1997. Intracellular esterase from Lactococcus lactis subsp. lactis NCDO 763: Purification and characterization. Int. Dairy J. 7:169-174.

Coppola, R., M. Nanni, M. Iorizzo, A. Sorrentino, E. Sorrentino, C. Chiavari, and L. Grazia. 2000. Microbiological characteristics of Parmigiano Reggiano cheese during the cheesemaking and the first months of the ripening. Lait 80:479-490.

Colchin, L. M., S. L. Owens, G. Lyubachevskaya, and S. A. Rankin. 2001. Modified atmosphere packaged Cheddar cheese shreds: Influence of light exposure and gas type on color and production of volatile compounds. J. Agric. Food Chem. 49:2277-2282.

Cristiani, G., and V. Monnet. 2001. Food micro-organisms and aromatic ester synthesis. Sci. Aliments 21:211-230.

Dumont, J. P., S. Roger, and J. Adda. 1974. Composés volatils du fromage entier et du fromage râpé: exemple du Parmesan. Lait 54:386-396.

Fenster, K. M., K. L. Parkin, and J. L. Steele. 2000. Characterization of an arylesterase from Lactobacillus helveticus CNRZ32. J. Appl. Microbiol. 88:572-583.

Fenster, K. M., K. L. Parkin, and J. L. Steele. 2003a. Intracellular esterase from Lactobacillus casei LILA: Nucleotide sequencing, purification, and characterization. J. Dairy Sci. 86:1118-1129.

Fenster, K. M., K. L. Parkin, and J. L. Steele. 2003b. Nucleotide sequencing, purification, and biochemical properties of an arylesterase from Lactobacillus casei LILA. J. Dairy Sci. 86:2547-2557.

Fernández, L., M. M. Beerthuyzen, J. Brown, R. J. Siezen, T. Coolbear, R. Holland, and O. P. Kuipers. 2000. Cloning, characterization, controlled overexpression, and inactivation of the major tributyrin esterase gene of Lactococcus lactis. Appl. Environ. Microbiol. 66:1360-1368.

Fox, P. F., T. P. Guinee, T. M. Cogan, and P. L. H. McSweeney. 2000. Cheese Flavor. Pages 282-304 in Fundamentals of Cheese Science. J. Colilla, ed. Aspen Publishers, Inc., Gaithersburg, MD.

Fox, P. F., and T. Cogan. 2000. Cheese: Scientific highlights of the 20th century. Pages 83-121 in 6th Cheese Symposium. T. M. Cogan, P. L. H. McSweeney, and T. P. Guinee, ed. Teagasc, Dublin, Ireland.

Gobbetti, M., P. F. Fox, and L. Stepaniak. 1996a. Esterolytic and lipolytic activities of mesophilic and thermophilic lactobacilli. Ital. J. Food Sci. 2:127-135.

Gobbetti, M., P. F. Fox, E. Smacchi, L. Stepaniak, and P. Damiani. 1996b. Purification and characterization of a lipase from Lactobacillus plantarum 2739. J. Food Biochem. 20:227-246.

Gobbetti, M., P. F. Fox, and L. Stepaniak. 1997a. Isolation and characterization of a tributyrin esterase from Lactobacillus plantarum 2739. J. Dairy Sci. 80:3099-3106.

Gobbetti, M., E. Smacchi, and A. Corsetti. 1997b. Purification and characterization of a cell surface-associated esterase from Lactobacillus fermentum DT41. Int. Dairy J. 7:13-21.

Ha, J. K., and R. C. Lindsay. 1992. Influence of $a_{w}$ on volatile free fatty acids during storage of cheese bases lipolyzed by kid goat pregastric lipase. Int. Dairy J. 2:179-195.

Ha, J. K., and R. C. Lindsay. 1993. Release of volatile branched-chain and other fatty acids from ruminant milk fats by various lipases. J. Dairy Sci. 76:677-690.

Holland, R., and T. Coolbear. 1996. Purification of tributyrin esterase from Lactococcus lactis subsp. cremoris E8. J. Dairy Res. 63:131-140.

Johnson, M. E. 2001. Cheese products. Pages 345-384 in Applied Dairy Microbiology. E. H. Marth and J. L. Steele, ed. Marcel Dekker, Inc., New York.

Kosikowski, F. 1977. Hard Italian cheeses. Pages 213-227 in Cheese and Fermented Milk Foods. F. Kosikowski, ed. Edwards Brothers, Inc., Ann Arbor, MI.

Lai, D. T., A. D. Mackenzie, C. J. O'Connor, and K. W. Turner. 1997. Hydrolysis characteristics of bovine milk fat and monoacid triglycerides mediated by pregastric lipase from goats and kids. J. Dairy Sci. 80:2249-2257.

Liu, S.-Q., R. Holland, and V. L. Crow. 2001. Purification and properties of intracellular esterases from Streptococcus theromophilus. Int. Dairy J. 11:27-35.

Martin, C. J., J. Golubow, and A. E. Axelrod. 1959. A rapid and sensitive spectrophotometric method for the assay of chymotrypsin. J. Biol. Chem. 234:294-298.

Meinhart, E., and P. Schreier. 1986. Study of flavour compounds from Parmigiano Reggiano cheese. Milchwissenschaft 41:689-691.

Moio, L., and F. Addeo. 1998. Grana Padano cheese aroma. J. Dairy Res. 65:317-333.

Qian, M., and G. Reineccius. 2002. Identification of aroma compounds in Parmigiano-Reggiano cheese by gas chromatography/olfactometry. J. Dairy Sci. 85:1362-1369.

Rüegg, M., and B. Blanc. 1981. Influence of water activity on the manufacture and aging of cheese. Pages 791-811 in Water Activity: Influences on Food Quality. L. B. Rockland and G. F. Stewart, ed. Academic Press, New York.

Sambrook, J., E. F. Fritsch, and T. Maniatis. 1989. Molecular Cloning: A Laboratory Manual. 2nd ed. Cold Spring Harbor Laboratory, Cold Spring Harbor, NY.

Tsakalidou, E., and G. Kalantzopoulos. 1992. Purification and partial characterization of an esterase from Lactococcus lactis ssp lactis strain ACA-DC 127. Lait 72:533-543.

Woo, A. H., and R. C. Lindsay. 1984. Concentrations of major free fatty acids and flavor development in Italian cheese varieties. J. Dairy Sci. 67:960-968. 